\title{
Mapping Memories through Geographic Information System: The Case of St Mark's Transdisciplinary Service-Learning Project in District Six, Cape Town
}

\author{
Nicholas Pinfold \\ Masilonyane Mokhele
}

\begin{abstract}
Through exploring the interconnections between transdisciplinarity and community service-learning, the paper presents ways in which geographic information system and allied methods and tools can be used to preserve and share the socio-spatial history of communities. The initiative that the paper is based on is known as St Mark's Church baptismal community service-learning project, which came into existence when the said church imagined resurrecting the spirit and soul of District Six by visualising its baptismal records. It was anticipated that the visualisation would show where congregants resided when they were baptised, before their community was unceremoniously demolished by the apartheid regime. Participants in the initiative included St Mark's Anglican Church, students (from Cape Peninsula University of Technology and Michigan University) and District Six Museum. During the initiative, a transdisciplinary space organically developed wherein students with different disciplinary backgrounds collaborated towards achieving the aim of the project. So as to draw lessons for future initiatives, the paper particularly focuses on the process followed, instead of emphasising the nitty-gritty details of the product (i.e. a Web map). Towards establishing a holistic socio-spatial history of District Six, it is hoped that the project will be scaled up to include stories and memories of individuals and groups beyond the St Mark's Church congregation.
\end{abstract}

Keywords: memory map, storytelling, geographic information system, District Six, Web map, transdisciplinary education 


\section{Introduction}

Land restitution is a topical element in South Africa, which is clouded by a struggle to resettle families that were displaced from their homes and communities by the apartheid regime. This undeniably hot topic (with profound political, economic and social ramifications) is more pertinent in light of the on-going debate on land expropriation without compensation (see Republic of South Africa 2019). Reflecting the relevance of land restitution in South Africa, a number of interrelated studies have been completed on the matter, primarily revolving around the relationship between land restitution and social justice (Mammon 2011) as well as the impact of policy and regulatory frameworks on land restitution processes (Berrisford 1999; Cousins 1998; Kihato \& Berrisford 2006; Le Grange \& Mammon 2010). To extend the literature, the aim of this paper is to use the case study of District Six, in Cape Town, to present ways in which geographic information system (GIS) and allied methods and tools can be used to document, restore, preserve and share the sociospatial history and memories of communities. Although the paper revolves around a community that was affected by forced relocations, the work presented herein can arguably be improved upon and applied to different contexts.

Focussing predominantly on the process followed towards documenting history, as opposed to emphasising a product, the paper draws on the concept of transdisciplinarity to show how different disciplines collaborated towards investigating, describing and visually presenting part of the rich history of District Six. A decision not to focus on the product was consciously taken so as to, among others, circumvent potential ethical concerns as discussed later in the paper. It is widely agreed that in transdisciplinarity, individuals or groups with different disciplinary backgrounds work together to contribute towards methods that integrate and transcend the perspectives of individual disciplines (Stokols et al. 2010; Wall \& Shankar 2008). It stands to reason that in that collaborative process, much-needed cross-fertilisation of knowledge and skills could be realised (Du Plessis et al. 2014). In a transdisciplinary approach, educators, students, professionals and/or researchers develop shared frameworks that go beyond discipline-specific concepts and methods towards creating a common approach to address a particular situation (Stokols et al. 2010). At an elementary level, the notion of transdisciplinarity acknowledges the complexity, interconnectedness and multidimensionality of reality; hence it calls for the need for use of more than 
one discipline towards exploring reality (Du Plessis et al. 2014; Martin 2017), which in the context of this paper is the socio-spatial history of communities.

The paper is located at the nexus between transdisciplinarity and community service-learning. Occurring in the context of community and university partnerships, community service-learning affords students an opportunity to work with communities on projects that would benefit the communities, while students learn in the process. This form of learning develops and augments the problem-solving skills of students and trains them to function in unfamiliar environments (Sletto 2010), while accordingly becoming familiar with socially contingent modes of knowledge generation (Elwood 2004). Upon this backdrop, it is widely argued that community service-learning contextualises knowledge production by giving students an opportunity to become educated in society's problems (Conner \& Erikson 2017; Hall 2010; Petersen \& Osman 2017; Pinfold 2014; Thomson et al. 2011) by being at the coalface of community issues.

The paper is structured as follows: the next section discusses the concepts of GIS and Web mapping as well as their significance in documenting and displaying socio-spatial data. The third section provides a brief overview of the case study of District Six that the paper is based on, including the rationale for case study selection. The fourth section unpacks the process that was implemented to document part of the socio-spatial history of the community of District Six. The fifth part synthesises (and reflects on) the process employed. The penultimate section discusses ethical concerns that characterised the project, followed by concluding remarks.

\section{Geographic Information System and Web Mapping}

As noted in the introduction, the paper explores intricate connections between transdisciplinarity, community service-learning as well as GIS and allied methods and tools. Lo and Yeung (2007) argue that it is not easy to define GIS because it could mean different things to different people. In some circles, GIS is regarded as a mere branch of information technology (IT), while others understand GIS more particularly as a computer-assisted mapping application, a set of spatial-analytical tools or a type of database system. It should nonetheless be noted that, contrary to what some people argue, GIS is not a map - it is a spatial analysis method and tool used to compile a map. Spatial analysis is a way of perceiving the world and to create a mental connection of 
where things are located in geographical space, and how they are connected (Erica et al. 2016). Although the graphic depiction of the data in GIS may appear to be a map, it only enables the user to think about the data better. In exploring the aforesaid interconnections, the discussion herein embraces the notion of qualitative GIS, which is broadly under-stood as technology, methodology as well as a situated social practice. As the name suggests, this approach encompasses qualitative information, which is not merely nonnumerical, but particularly implies that the information entails rich contextual detail about given situations; and also provides interpretation of the situations or processes of interest (Elwood \& Cope 2009).

The allied tool explored in the paper is Web mapping, which has become a popular online tool for presenting and disseminating geographic information. A Web map is a true map that can display GIS output using auxiliary software (van Der Merwe 2003). In this way, displaying information on a map embraces digital media as a potentially powerful tool for allowing the wider community access to information (Murray 2017). When compiling a map using geographic information and aerial images, intangible artefacts (such as stories) help present an overall image of the place that is embedded in particular social, political, economic and spatial practices. A Web map can be static with the so-called 'view only' function or can be dynamic and interactive. Visualising information using an interactive map can provide a better understanding of the uniqueness and significance of a place. If a user is able to zoom, pan and identify objects on a map as well as turn data layers on and off, it becomes easier for them to visualise issues relating to the area of interest (Doyle et al. 1998). When displayed on the Web, the map becomes an active source that allows the gathering of timelines, historical events, current events, and prediction of future events. This is critical because understanding the past helps us as individuals and society to better understand the present and imagine the future (Steyn 2018).

Against the backdrop above, as argued by Lo and Young (2007), it is clear that in GIS, the screen of a computer has essentially replaced paper as a primary form of maps. This shift has accordingly changed the ways by which information is portrayed on a map. Compared to the static view that characterises the paper map, in the era of GIS, geospatial information is predominantly presented dynamically on the screens of computers. In addition, geospatial information can be portrayed in various forms i.e. as a perspective view, an animation, a fly-through or a simulation (Lo \& Yeung 2007). It should 
be acknowledged that visualisation is arguably the most widely used function in GIS. Like other tools for graphic data displays, GIS makes spatial information immediately accessible to the minds of the users (Pavlovskaya 2009). The product of the project presented herein was visualisation through a Web map. However, as noted in the introduction, the emphasis of the paper is on the process that was followed towards creating the map. The discussion therefore does not include a detailed discussion or nitty-gritty details of the Web map developed.

\section{A Brief Overview of District Six}

The paper explores the case study of District Six, which is located on the edge of contemporary Cape Town central business district (CBD), at the bottom of Table Mountain (see Figure 1 below).

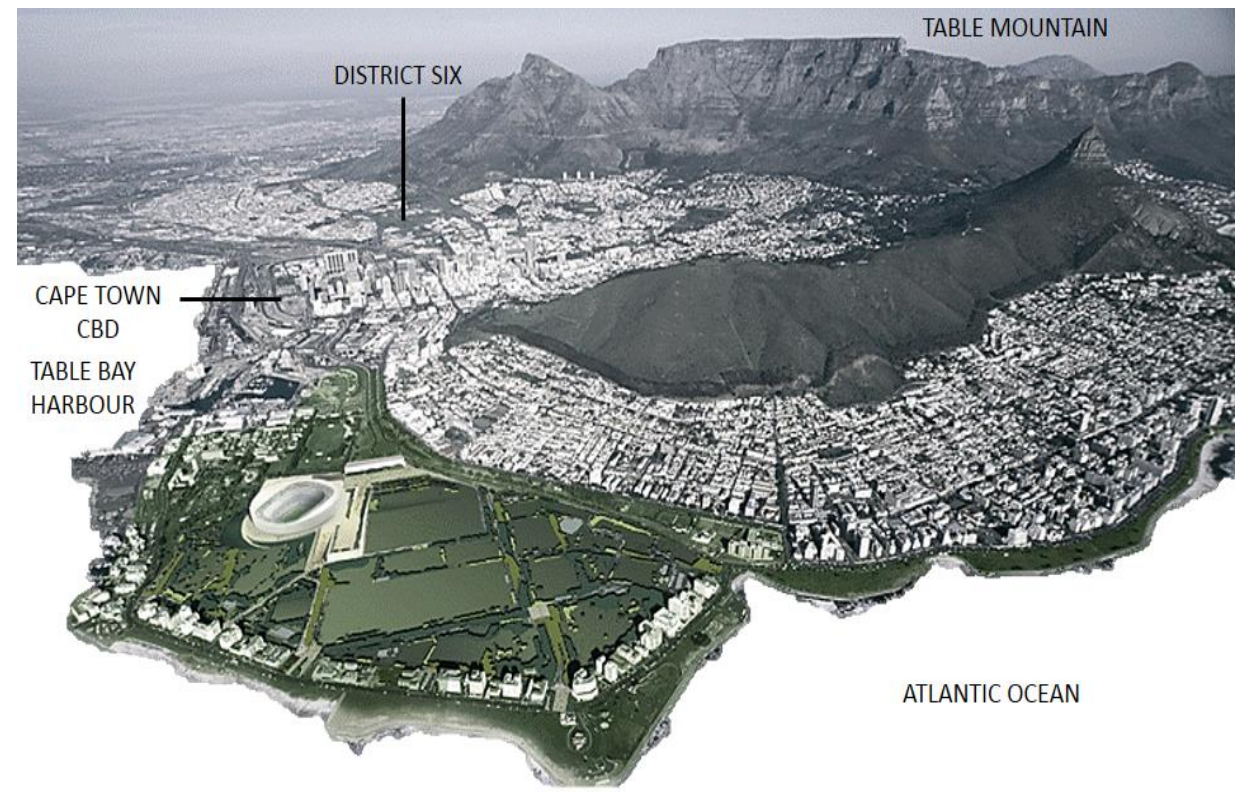

Figure 1: Source: https://encrypted-

tbn0.gstatic.com/images?q=tbn\%3AANd9GcQVUbUCBa6_sBcD9mpdedI6t FbDzLGK0OQjUcZwU2YQASk3h95M\&usqp=CAU 
It is well known that District Six has for years been the subject of a restitution claim in terms of Restitution of Land Rights Act No. 22 of 1994. During apartheid, an area measuring between 114ha and 150ha in District Six was proclaimed a White Group Area, resulting in the removal of about 60000 residents (Mammon 2011). The residents were forcibly removed from their homes between 1969 and 1984 and relocated to designated racial areas. Most of the buildings in District Six were in the process demolished, apart from a few places of worship such as mosques and the St Mark's Anglican Church built in 1867. As elaborated hereunder, the transdisciplinary service-learning initiative that is the subject of the paper was centred on the St Mark's Church.

District Six offers a unique case not only because it was one of the largest forced relocations in the country but also given that it suffers from slow progress as regards the resettlement of the affected families. Most of the original residents of District Six passed away before the realisation of the return to their beloved area, hence it is important to capture the memories and social-spatial history from those who are still alive. The redevelopment of District Six has been slow potentially due to a number of reasons, including a land restitution process that is fraught with political difficulty and a social development agenda that is, among others, struggling against a lucrative property market (Layne 2008). As implied in the introduction, District Six has been the subject of a plethora of insightful studies (for instance, see Mammon 2011), which the current paper intends to extend from a different angle.

\section{Mark's Baptismal Community Service-Learning Project}

The initiative that is the subject of the paper is known as St Mark's Church baptismal community service-learning project in District Six. Before presenting the project, two considerations should be noted in light of the assertion in the introduction that the paper explores the interconnections between community service-learning and transdisciplinarity. Firstly, the initiative was not designed as a research project but was devised as a mere service-learning project (also see a discussion of ethics hereunder). Secondly and relatedly, the initiative was not consciously set-up as a transdisciplinary project. Notwithstanding this declaration, it was realised during the servicelearning activities that the initiative was organically evolving in leaps and bounds to bear some resemblance to transdisciplinary education. It was then decided that the process should be reported on so as to draw lessons that could in part be used to inform other initiatives that explore the nexus between com- 
munity service-learning and transdisciplinarity.

There are various ways in which community service-learning projects, transdisciplinary projects or similar initiatives come into being. Showing that there is no silver bullet, in some instances, community-based organisations approach universities to assist with particular issues in the community (for instance, see Winkler 2013); or, through what is typically referred to as the 'shop front model', universities advertise themselves in a bid to attract community engagement partners. This model is collaborative and has the potential to be multidisciplinary, interdisciplinary or indeed transdisciplinary. Community groups, academics and students work together in all facets of a community engagement project within an innovative and supportive environment. This collaborative approach ensures a uniform way of dealing with community groups (see Smith-Tolken 2012).

With that backdrop in mind, given that St Mark's Church baptismal project was not meticulously pre-planned and designed, the origin of the project as well as the inclusion of various community and academic stakeholders evolved organically. As a starting point, the project came into being following the request for assistance that Cape Peninsula University of Technology's (CPUT's) Department of Town and Regional Planning received from St Mark's Anglican Church. One of the senior church leaders had serendipitously met a lecturer from the aforesaid department at the Heritage Day celebration event that was organised by CPUT's Service-Learning Unit in 2017. That meeting, which happened by chance, formed a foundation for the project. Upon receiving the request, the Department of Town and Regional Planning headed the call and agreed in principle to collaborate and lend a helping hand to the church. That foundation was followed by the extension of stakeholders largely based on informal academic and social networks. Given his extensive experience and knowledge of District Six, the Department of Town and Regional Planning invited a colleague from another faculty of the university to partake in the project. The colleague agreed and in turn invited a counterpart from the University of Michigan (in the United States of America) to also collaborate on the project. The two acquaintances knew each other through social networks. Following the initial discussions between the aforesaid actors, it was decided that District Six Museum be approached to partake in the project as it was arguably best placed to serve as a repository of the product of the project, and particularly well suited to openly share the information with the wider community. The District Six Museum embraced 
the invite and agreed to be the repository of the future material (digital or otherwise) to, among others, ensure the publicity and sustainability of the project.

As a result of the aforesaid web of academic and social networks, the following stakeholders participated in the St Mark's Church baptismal community service-learning project: St Mark's Anglican Church, CPUT (Department of Town and Regional Planning and Department of Geomatics/ Surveying), University of Michigan (various departments) and the District Six Museum. Per the requirements of the university, CPUT's Service-Learning Unit subsequently registered the initiative as a community service-learning project. This unit was also meant to, among other roles, provide logistical support and ensure the overall success of the initiative.

When St Mark's Church first approached CPUT, its leadership had imagined, as it were, resurrecting the soul of District Six by 'visualising' the baptismal records, which would entail showing where the baptised individuals resided in District Six prior to the forced relocations. In this regard, the project was intended to memorialise the heritage of District Six by geo-referencing baptismal records archived in the St Mark's Church (which preceded 1968 when forced removals were implemented) and capture the stories of the affected individuals through dialogue, pictures and other artefacts. The ultimate aim of the collaboration was to develop an interactive Web (GIS) map to display the baptismal records on the District Six Museum's website. Openly accessible, it was intended that the map would among others be used to educate the wider community (particularly the youth) on the history of District Six, and provide former residents a place to reminisce and be recognised (Cox et al. 2019). It was ultimately agreed that the scope of the community servicelearning initiative would encompass three main elements, namely:

(1) collection and analysis of data from the baptism records kept by St Mark's Church;

(2) use of GIS and allied tools to display the data as an interactive Web map; and

(3) capturing of the stories of District Six so far as they related to individuals on the baptism records, and ultimately incorporating those stories into the Web map. 
Although it is difficult to pinpoint the exact inception month of the project, the initiative started in earnest in 2018 following the preliminary discussions between CPUT and the church in 2017. Approximately 124 students from two faculties and departments of CPUT, and various departments of the University of Michigan subsequently participated in the project in 2018 and 2019 (see Table 1). The activities of the project were linked to the respective disciplinary subject requirements of the different departments and universities. As reflected in Table 1, the University of Michigan students were from diverse disciplines including information science, social work, public policy and urban planning. They were also studying at different levels ranging from undergraduate degrees to doctorate. Students from the University of Michigan were part of the 2018 and 2019 Global Information Engagement Program (GIEP) hosted at their university. The aim of GIEP was to explore the complex relationships between people, information and technology; hence it was anticipated that the students would learn from the St Mark's Church baptism project while also providing valuable input for the realisation of the aim of the project. During their stint in Cape Town, the Michigan students worked closely with the Department of Town and Regional Planning where they were offered a working space with the requisite access to computers and the Internet. The students also had a working space at the District Six Museum.

The participants from CPUT included academic staff and first-year and third-year students completing the diploma-level qualifications in Urban/ Town and Regional Planning, as well as third-level students enrolled in the National Diploma in Geomatics. With the project largely related to mapping, the project activities were linked to the so-called 'technology-related' subjects at CPUT. To reflect this state of affairs, Town and Regional Planning first-year students were enrolled in the subject 'Information Systems' while third-year students were completing the subject 'Geographic Information Systems'. Information Systems is a subject wherein students learn how to manipulate numeric data in a spreadsheet and relate tables using a database management system. Students are taught to recognise what data are needed and how to organise the data. The practical part of the subject teaches students the rationale of applying computer-aided design (CAD) in urban planning. Geographic Information Systems is a subject that deals with the fundamentals of geospatial information, including understanding spatial concepts and spatial analysis. The aim of the subject is to expose students to hands-on use of commercial GIS software. Practical classes in this regard require a significant commitment of 
time and attention in managing geospatial projects. In some instances, students are expected to complete these projects in groups. The subject is intended to prepare students as, among others, planning technicians working in government and non-governmental sectors.

Though not consciously designed and set-up as such, a transdisciplinary space emerged in the attempts to integrate the various disciplines and provide shared meaning and a connection to the past of District Six. This integration was meant to give opportunity to groups from diverse disciplines to contribute to the process while willing to learn from the standpoint of other project members.

Table 1: Number of students involved in the St Mark's Church project between 2018 and 2019

\begin{tabular}{|l|l|l|l|}
\hline University & Discipline & $\begin{array}{l}\text { Level of } \\
\text { study }\end{array}$ & $\begin{array}{l}\text { Number of } \\
\text { students }\end{array}$ \\
\hline $\begin{array}{l}\text { Cape Peninsula } \\
\text { University of } \\
\text { Technology }\end{array}$ & $\begin{array}{l}\text { Urban and } \\
\text { regional planning }\end{array}$ & $\begin{array}{l}\text { Diploma (first } \\
\text { year and third } \\
\text { year) }\end{array}$ & 87 \\
\hline $\begin{array}{l}\text { Cape Peninsula } \\
\text { University of } \\
\text { Technology }\end{array}$ & $\begin{array}{l}\text { Geomatics } \\
\text { (Survey) }\end{array}$ & $\begin{array}{l}\text { Diploma } \\
\text { (third year) }\end{array}$ & 30 \\
\hline $\begin{array}{l}\text { University of } \\
\text { Michigan }\end{array}$ & $\begin{array}{l}\text { Information } \\
\text { science } \\
\text { Social work } \\
\text { Public policy } \\
\text { Urban planning }\end{array}$ & $\begin{array}{l}\text { Master's and } \\
\text { doctoral }\end{array}$ & 7 \\
\hline Total & & & $\mathbf{1 2 4}$ \\
\hline
\end{tabular}

Towards achieving the aim of the project (i.e. the development of a Web map), the students employed a mixed method of data collection comprising the following sources of information:

1) Paper manuals of baptism records obtained from the archives in the vault of St Mark's Church. The records included information in five sections, namely: 'When baptised', 'Name information', 'Abode', 'Sponsors/ witnesses/ rector' and 'Additional information'. The following information was included in each section: 
- 'When baptised' section: date of when the baptism occurred; and the number of the baptism record in the baptismal sequence.

- 'Name information' section: surname; given name (i.e. Christian name); father listed under the parent's names; mother listed under the parent's names; date of birth.

- 'Abode' section: the numeral part of the address; building name (such as an apartment building/flats; street name); type i.e. the street name suffix; city or suburb; other information; profession.

- 'Sponsors/witnesses/rector' section: surname; given name; the person who facilitated the baptism.

- 'Additional information' section: differentiate District Six addresses from non-District Six addresses; additional archival information; internal notes needed during the data extraction process, such as referencing making a note about illegibility or missing information that can be addressed later.

2) Geo-referenced raster images of District Six for the period 1960 to 1984, obtained from National Geo-spatial Information (NGI), a component of Department of Rural Development and Land Reform (DRDLR), also known as South Africa's national mapping organisation. The aforesaid period was selected so as to capture trends of the spatial structure over time.

3) Face-to-face interviews with key informants i.e. selected number of individuals who were baptised at St Mark's Church prior to the forced relocations.

After obtaining the scanned baptism records from the church, the main task was to convert the images into editable text. The editable text was required for building attribute information linked to its geo-referenced feature point. An attempt was made to use Optical Character Recognition (OCR) software to convert the images into editable text. OCR uses character recognition to automatically extract text from images (Hamad \& Kaya 2016). Significant challenges were however encountered in the use of OCR, which included characters not being recognised correctly due to a dark and noisy background, and difficulty in recognising cursive scripts and handwritten text. Given the 
aforesaid challenges, the use of OCR was stopped and data had to be manually entered into the Microsoft Excel spreadsheet. The data was subsequently cleaned to particularly eliminate spelling and physical address errors. The cleaning was done using a customised Python script file that, when run, automatically compared and corrected the spelling of street names in the spreadsheet. Any information that was illegible was corroborated using other sources. So as to make the data useable across the board, the format of the spreadsheet was made consistent with the expected standards of the different departments and universities involved in the project.

Certain spatial features were digitised from the 1968 plan to create a map that provided sufficient information required for analysis of the spatial layout of District Six at the time. The rationale for selecting the 1968 raster image was to portray District Six at its peak, in the mid 60s, right before the commencement of removals. Before providing the details of the map, it should be noted that in the context of GIS, three forms (namely vector, raster and attributes) are used to represent geospatial data. Vector data, which are ideal for natural and artificial features that can be individually identifiable, represent the features by points, lines, and polygons. Raster data represent the real world by means of a grid of cells with spectral values. This type of data is not good for representing individually identifiable features but is ideal for a variety of spatial analysis functions. Lastly, attribute data denote non-location information related to a point, a line, or a polygon (Lo \& Yeung 2007).

For the St Mark's Church baptismal project, the three primary vector feature classes captured were physical address location, building footprint and the street network. The vector symbol used for the address locator was a point positioned at the location of the property, labelled with attributes indicating the street address. Building footprints were captured using the polygon vector feature labelled with attributes detailing the class of land use on which the buildings were erected. Street addresses and land use were essential in understanding and assessing the legibility, accessibility, variety and robustness of District Six prior to the forced relocations. The street network was captured using a line vector feature with attributes indicating the street name and type. Notably, the small grid layout and straight streets of the old District Six has been mostly retained.

After a GIS map was compiled, the data in the spreadsheet extracted from the baptism records were joined by key field to the 'address' feature class attribute table. This was done to link the information extracted from the 
baptism records to the location of the person baptised. It was important that multiple tables were linked in a relational database. Each table could then be individually focused on a specific theme of information. When joining tables, the attributes of the secondary table were appended to the attributes of the parent table. Two tables could also be related without being joined if the secondary table had to be regularly edited and updated. An advantage of having multiple tables is that it prevented the duplication of information in the database (Gimond 2019).

Following the use of secondary information above, discussions were held with a sample of the former residents of District Six who were part of the baptismal records in St Mark's Church. With the assistance of the church and District Six Museum, six participants (who appeared in the baptism records) took part in the interviews, which were conducted on the premises of St Mark's Church on Sundays after church service. Through accessing information from the horse's mouth, such engagement was key in ensuring that the data were correctly described and interpreted. People who once lived in District Six were able to provide the context needed to link the baptismal records to the actual places they described. The process enabled students to better understand the data and appreciate the connection that the former residents had with District Six. As mentioned earlier, the community engagement, facilitated by the $\mathrm{St}$ Mark's Church, helped identify a pilot group of seven former residents of District Six who were interested in sharing their stories. The St Mark's Church hosted an event for the seven volunteers to share their stories with stakeholders and students. Stories from the volunteers were used to create a prototype for linking oral histories and personal archival collections with the GIS map. Oral histories and artefacts such as photographs were incorporated into the GIS object-orientated database. It is well known that oral histories are important because they contextualise people in distinct places over time, which in the context of the paper is the former residents of District Six (Aitken \& Craine 2009). Pavlovskaya (2009) asserts that integrating interviews in GIS is important as a means of acknowledging and including the affected individuals as co-creators of representations informed by their personal experiences.

Emanating from the process above, an interactive memory map to be published on the Internet (which can even be accessed on a smartphone application) will have a significant value in displaying intangible cultural and heritage information of District Six. In this way, Internet provides an online 
platform from which the District Six Museum can disseminate information that transcends pure documentation. Furthermore, the museum would be able to display these memories without being confined to an exhibition within its buildings (Alivizatou 2016). It is hoped that in this way, culture will be transmitted from generation to generation and will be constantly updated in the future. It is further anticipated that the resultant sense of identity will promote respect for cultural diversity and human creativity in District Six. The museum acknowledges that their most important function is to collect memories and stories, which they then give back to the broader community. The museum is a space for people to talk about what kind of community they had and want in future, and encourage people to act (Layne 2008).

\section{A Space for Transdisciplinary Engagement: Synthesis and Reflection}

As part of a community service-learning process, the students provided their specific disciplinary input to the collection, analysis and visualisation of data at different stages of the St Mark's Church baptismal project. Students from CPUT's Department of Town and Regional Planning and Department of Geomatics/ Surveying applied their basic GIS knowledge to digitise property location using a point feature with address attributes from the 1968 District Six map. Students were in the process exposed to the value of geo-locational knowledge for visualising heritage records. First-year students at CPUT (who possessed basic conceptual understanding of computer technology, computer aided drafting, GIS and database manage-ment) contributed to the project by checking the integrity of electronic data scanned from paper records. The benefit for first-year students was the acqui-sition of practical knowledge of virtual geo-locational archives through data-base management. Third-year students from the two faculties at CPUT collabo-rated in digitising property locations using the 1968 District Six reference map. These students were equipped with a more advanced understanding of precision drawings in twodimensional (2D) and three-dimensional (3D) as well as GIS. The project accordingly exposed third-year students to the value of geo-locational knowledge for visualising heritage information.

As noted earlier, the University of Michigan students were from diverse disciplines including information science, social work, public policy, and urban planning. They were tasked with the extraction of relevant 
information from the archived baptismal records and development of a basic framework for data capture, and to initiate community engagement with the former residents of District Six. The community engagement aspect of GIEP (which the students were part of) intended to promote active interaction and engagement with community members, encouraging the students to work collaboratively. In 2019, four new students from the University of Michigan GIEP joined the St Mark's Church baptismal project. The new students worked under the guidance of the District Six Museum, who were tasked with the publishing of the interactive map on their website. The map built upon the work previously done by the 2018 GIEP cohort. The aim was to use affordable offthe-shelf software that was relatively easy to set-up and use. CPUT students contributed by providing additional spatial data captured during the 2018 activities. Follow-up interviews were conducted with the seven former residents who participated in the project in 2018 to clarify evidence and capture any information that was missed during the first interviews. The spreadsheet of their baptismal records was linked to the geo-referenced street names and addresses in GIS software along with digitised historical building footprints captured by lecturers and students at CPUT.

The collaboration between the students from CPUT, the University of Michigan and the former residents was mainly through the St Mark's Church and District Six Museum where contact sessions and related activities were arranged. Collaboration involving scholars and students from diverse disciplines, at different academic levels during the project indeed provided a unique learning experience. Table 2 below shows the value that was added to the project after the students from various disciplines interacted with a common goal of contributing towards the development of a Web map or virtual GIS map.

\section{Table 2: A summary of expectations before and after transdisciplinary collaboration}

Project Objective: Extraction of archived baptisms records (pre-1982) kept in the St Mark's Church in order to build a virtual GIS map (of District Six before it was demolished) that records the location of residents baptised in District Six at the time. This was intended to reconnect former District Six residents to the current neighbourhood in the hope to revive community and increase awareness of the rich history and cultural heritage of the old District Six. 


\begin{tabular}{|c|c|c|}
\hline Participants & $\begin{array}{l}\text { Expected } \\
\text { contribution - } \\
\text { multi/inter- } \\
\text { disciplinary }\end{array}$ & $\begin{array}{l}\text { Contribution after } \\
\text { transdisciplinary } \\
\text { collaboration }\end{array}$ \\
\hline $\begin{array}{l}\text { School of Information } \\
- \\
\text { University of } \\
\text { Michigan }\end{array}$ & $\begin{array}{l}\text { Data extraction } \\
\text { workflow design, data } \\
\text { extraction database } \\
\text { management. }\end{array}$ & \multirow{6}{*}{$\begin{array}{l}\text { - Audio 'story-telling' } \\
\text { was introduced. } \\
\text { - Discipline specific } \\
\text { questions transcended } \\
\text { the scope of inquiry. } \\
\text { - St Mark's Church } \\
\text { helped provide technical } \\
\text { support for oral story- } \\
\text { telling. } \\
\text { - Oral histories } \\
\text { incorporated in the GIS } \\
\text { object-orientated } \\
\text { database. } \\
\text { - All disciplines } \\
\text { participated in } \\
\text { community engagement } \\
\text { activities on Sundays } \\
\text { after church resulting in } \\
\text { comprehensive } \\
\text { collaboration. } \\
\text { - During community } \\
\text { engagement students } \\
\text { were able to present } \\
\text { their work while } \\
\text { community members } \\
\text { used the GIS map to } \\
\text { share abbreviated } \\
\text { versions of their stories. }\end{array}$} \\
\hline $\begin{array}{l}\text { School of Social Work } \\
- \\
\text { University of } \\
\text { Michigan }\end{array}$ & $\begin{array}{l}\text { Community } \\
\text { engagement and } \\
\text { community outreach. }\end{array}$ & \\
\hline $\begin{array}{l}\text { School of Urban } \\
\text { Planning - } \\
\text { Ford School of Public } \\
\text { Policy, University of } \\
\text { Michigan } \\
\text { Department of Town } \\
\text { and Regional } \\
\text { Planning, Cape } \\
\text { Peninsula University } \\
\text { of Technology }\end{array}$ & $\begin{array}{l}\text { Establish a sense of } \\
\text { place, understand } \\
\text { local context and } \\
\text { public planning } \\
\text { policy. }\end{array}$ & \\
\hline $\begin{array}{l}\text { Department of } \\
\text { Geomatics (Survey) - } \\
\text { Cape Peninsula } \\
\text { University of } \\
\text { Technology }\end{array}$ & $\begin{array}{l}\text { GIS mapping and } \\
\text { develop a geo-address } \\
\text { locator }\end{array}$ & \\
\hline $\begin{array}{l}\text { Community - St } \\
\text { Mark's Church } \\
\text { congregation members }\end{array}$ & $\begin{array}{l}\text { Former population of } \\
\text { District Six who were } \\
\text { forcibly removed and } \\
\text { relocated during } \\
\text { Apartheid }\end{array}$ & \\
\hline $\begin{array}{l}\text { Community Based } \\
\text { organisation - District } \\
\text { Six Museum }\end{array}$ & Custodian of data & \\
\hline
\end{tabular}


The students who took part in the project were given opportunity to reflect on their participation and accordingly make suggestions on how the project (or similar projects on the nexus between community service-learning and transdisciplinarity) can be improved. The general consensus of CPUT students was that the project had significant value but should be expanded to include a wider group of community members that resided in District Six before the forced relocations. The more embracing group would include, for instance, individuals from other Christian denominations or churches and other faith groups such as Muslim and Jewish. Students also suggested that the Web map be expanded to show information such as heritage protection zones, cultural sites and current developments in the environs of District Six as well as land restitution sites across Cape Town.

Similarly, students from the University of Michigan acknowledged that the small group of informants (storytellers) was limiting and recommended that as the project develops and matures, a more diverse group of storytellers be included. The initial group of storytellers were arguably not a comprehensive representation of the diversity of District Six and that future storytellers could be found through schools, mosques, Jewish social centres, various churches, or other non-religious outlets. The students also suggested that District Six Museum could host a series of workshops with former residents to gather more memories. The students also commented that the data used requires development. Although the data used includes most of District Six, there are a couple of spots where information is missing. They also noted the existing data could be better validated and scrutinised for mistakes. Improving the integrity of the data could be achieved through crowdsourcing, which would however require constant upkeep in the verification of information added to the map.

Finally, as alluded to throughout the paper, the initiative was not transdisciplinary in the strict sense. The activities evolved organically to show potential and largely bear resemblance to a transdisciplinary project. In light of the reflection and lessons above, the intention is that the project will be scaled up in future and will eventually include stories from groups outside of St Mark's Anglican Church. The expanded initiative would particularly be designed as a transdisciplinary research and education project wherein the requisite approvals (ethics-related or otherwise) would be obtained before further investigations are conducted. 


\section{Ethical Matters}

As a standard requirement, CPUT's Service-Learning Unit registered the St Mark's Church baptism initiative as a service-learning project. Despite the fact that the initiative was not designed as a research project as discussed earlier, ethical considerations were high on the agenda during the service-learning process as well as at the stage when a decision was taken to reflect and report on the experience. During the service-learning process, written consent was obtained from the seven informants (that were baptised at the St Mark's Church) selected as the sample for the project. The respondents accordingly gave permission that their stories, photographs and other artefacts could be published. Despite the consent given, it was acknowledged that there remained an ethical risk if someone else (i.e. other than the individuals interviewed) contested the claim on ownership of the properties published in the St Mark's Anglican Church baptism register and confirmed by the key respondents. If such situation arose, there wouldn't be a way of confirming beyond doubt who the actual former owners or occupants of the properties were. Additionally, in light of the limited number of respondents, it was acknowledged that there was a risk that the 'published' information could be considered controversial, partially because the pool of perspectives was not diverse (Cox et al. 2019).

Due to the aforesaid concerns, it was decided not to report on any personal information (such as the baptism register, names of community members who participated in the project and the actual Web map) and rather focus on the community service-learning process followed. Furthermore, despite the focus on process, photographs of the students, academic staff, church leaders and other stakeholders are not included in the paper so as to maintain confidentiality and anonymity.

\section{Conclusion}

St Mark's Church baptismal community service-learning project was a partnership between St Mark's Anglican Church, Cape Peninsula University of Technology, the University of Michigan and District Six Museum. The objective of the project was to map District Six as it was before it was demolished and geo-reference on the map the location of people baptised at the St Mark's Anglican Church. The virtual reconstruction of the archives of the baptism records on a map was intended to reignite the community of District Six and memorialise its heritage into a virtual map that physically reconnects 
people to District Six despite there being no physical connection given the pending restitution process. The visual representation of the past is arguably one of the powerful mechanisms to achieve societal healing and reconciliation. The interactive map not only provides a spatial account of belonging but also geo-references oral accounts of the history of people's genealogy in District Six. The map is a tangible account of heritage information, making invisible history visible. The digital information collected includes storytelling audiotapes, photographs, GIS databases, and documents. Community participation in the planning, resettlement and development process of District Six is of fundamental importance. The association the residents have with District Six is linked to intangible social and cultural values and not simply the former physical environment. Although St Mark's Church baptismal community service-learning project started as a multi/ interdisciplinary service-learning project, it soon became evident that a transdisciplinary approach was in essence developing. It is hoped that this experience will be built upon and used to improve the initiative as well as other projects that explore the interconnections between community service-learning and transdisciplinarity.

\section{References}

Aitken, S.C. \& J. Craine 2009. Into the Image and Beyond: Affective Visual Geographies and GIScience. In Cope, M. \& S. Elwood (eds.): Qualitative GIS: A Mixed Methods Approach. London: Sage.

Alivizatou, M. 2006. Museums and Intangible Heritage: The Dynamics of an 'Unconventional' Relationship. Papers from the Institute of Archaeology 17: 47-57.

https://doi.org/10.5334/pia.268

Berrisford, S. 1999. Redistribution of Land Rights in South Africa: Simply a Rural Question? IRGLUS/ CALS Workshop Redefining Property Rights in an Era of Liberalisation and Privatisation. University of Witwatersrand, Johannesburg, South Africa, 29- 30 July 1999.

Conner, J. \& J. Erickson 2017. When does Service-learning Work? Contact

Theory and Service-learning Courses in Higher Education. Michigan Journal of Community Service Learning 23, 2: 53 - 65.

https://doi.org/10.3998/mjcsloa.3239521.0023.204

Cousins, B 1998. How do Rights become Real? Formal and Informal Institu- 
tions in South Africa's Tenure Reform Programme. In Barry, M. (ed.): Proceedings of the International Conference on Land Tenure in the Developing World: With a Focus on South Africa. Cape Town: University of Cape Town.

Cox, V., V. Dall, V. Qiu \& J. Yelk 2019. District Six Museum St Mark's Memory Capture and Interactive Mapping. Project Report.

Doyle, S., M. Dodge \& A. Smith 1998. Mapping and Virtual Reality.

Technologies for Urban Modelling 22,2: 137 - 155.

https://doi.org/10.1016/S0198-9715(98)00014-3

Du Plessis, H., J. Sehume \& L. Martin 2014. The Concept and Application of

Transdisciplinarity in Intellectual Discourse and Research. Woodmead:

Real African Publishers.

Elwood, S.A. 2004. Experiential Learning, Spatial Practice, and Critical Urban

Geographies. The Journal of Geography 103, 2: 55 - 63.

https://doi.org/10.1080/00221340408978576

Elwood, S. \& M. Cope 2009. Introduction: Qualitative GIS: Forging Mixed Methods Through Representations, Analytical Innovations, and Conceptual Engagements. In Cope, M. \& S. Elwood S (eds.): Qualitative GIS: A Mixed Methods Approach. London: Sage.

Erica, L., P. Nelson \& G. Greenough 2016. Geographic Information Systems in Crises. Available at:

https://www.sciencedirect.com/topics/medicine-and-dentistry/spatialanalysis

(Accessed on 06 January 2019.)

Gimond, M. 2019. Intro to GIS and Spatial Analysis. Available at: https://mgimond.github.io/Spatial/index.html (Accessed on 1 June 2019.)

Hall, M. 2010. Community Engagement in South African Higher Education. In Community Engagement in South African Higher Education. Pretoria: Jacana Media.

Hamad, K.A. \& M. Kaya 2016. A Detailed Analysis of Optical Character Recognition Technology. International Journal of Applied Mathematics, Electronics and Computers 4, Special Issue: 244 - 249. https://doi.org/10.18100/ijamec.270374

Kihato, M. \& S. Berrisford 2006. Urban Landmark Position Paper 4. Urban Land Seminar. Available at:

http://www.urbanlandmark.org.za/downloads/04_Kihato_Berrisford.pdf (Accessed on 06 January 2019.) 
Layne, V. 2008. The District Six Museum: An Ordinary People's Place. The Public Historian 30, 1: 53 - 62. https://doi.org/10.1525/tph.2008.30.1.53 Le Grange, L. \& N. Mammon 2010. District Six Development Framework: Prospects for Urban and Social Sustainability. In Pieterse, P. (ed.): Counter-currents: Experiments in Sustainability the Cape Town Region. Cape Town: Jacana Media.

Lo, C.P. \& A.K.W. Yeung 2007. Concepts and Techniques of Geographic Information Systems. Upper Saddle River, New Jersey: Pearson Prentice Hall.

Mammon, N. 2011. The Urban Land Question: Management and Access for the Urban Poor in Post Apartheid South Africa. PhD thesis, University of cape Town.

Martin, V. 2017. Transdisciplinarity Revealed: What Librarians Need to Know. California: Libraries Unlimited.

Murray, S. 2017. Creative Cardiff: Utilising Cultural Mapping for Community Engagement. Available at:

https://doi.org/10.1016/j.ccs.2017.08.003

Petersen, N. \& R. Osman 2017. An Introduction to Service Learning in South Africa. In Osman, R. \& N. Petersen (eds.): Service Learning in South Africa. Cape Town: Oxford University Press.

Pavlovskaya, M. 2009. Non-quantitative GIS. In Cope, M. \& S. Elwood (eds.): Qualitative GIS: A Mixed Methods Approach. London: Sage.

Pinfold, N. 2014. Generating New Knowledge with and in a Community Setting. Paper presented at Planning Africa 2014 conference, South African Planning Institute, Durban, 19-22 October.

Republic of South Africa (Advisory Panel on Land Reform and Agriculture) 2019. Final Report on the Presidential Advisory Panel on Land Reform and Agriculture. Available at:

https://www.gov.za/sites/default/files/gcis_document/201907/panelrepor tlandreform 1.pdf (Accessed on 29 July 2019.)

Sletto, B. 2010. Educating Reflective Practitioners: Learning to Embrace the Unexpected through Service Learning. Journal of Planning Education and Research 29,4: 403 - 415.

Smith-Tolken, A. 2012. Perspectives on the Shopfront Model of the University of Technology, Sydney (Australia). Stellenbosch University Community Interaction. Symposium Report 2012. Conceptualising Community Engagement Interaction for a $21^{\text {st }}$ Century University. 
Steyn, D. 2018. From the Editor. Town and Regional Planning 72: i - ii.

Stokols, D., K.L. Hall, R.P. Moser, A. Feng, S. Misra \& B.K. Taylor 2010.

Cross-disciplinary Team Science Initiatives: Research, Training, and Translation. In Frodeman, R., J.T. Klein, C. Mitcham \& J.B. Holbrook (eds.): The Oxford Handbook of Interdisciplinarity. New York: Oxford University Press.

Thomson, A.M., A.R. Smith-Tolken, A.V. Naidoo R.G. \& Bringle 2011. Service Learning and Community Engagement: A Comparison of Three National Contexts. Voluntas 22: 214-237.

https://doi.org/10.1007/s11266-010-9133-9

Van Der Merwe, F. 2003. GIS, Maps and Visualisation. $21^{\text {st }}$ International Cartographic Conference (ICC), Durban, South Africa.

Wall, S. \& I. Shankar 2008. Adventures in Transdisciplinary Learning. Studies in Higher Education 33, 5: 551 - 565.

https://doi.org/10.1080/03075070802373008

Winkler, T. 2013. At the Coalface: Community-University Engagements and Planning Education. Journal of Planning Education and Research 33, 2: 215 - 227. https://doi.org/10.1177/0739456X12474312

Nicholas Pinfold Department of Town and Regional Planning Cape Peninsula University of Technology

Cape Town pinfoldn@cput.ac.za

Masilonyane Mokhele Head of Town and Regional Planning Department Cape Peninsula University of Technology

Cape Town mokhelem@cput.ac.za 